\title{
PRINCIPAIS ALTERAÇÕES NO NOVO CÓDIGO FLORESTAL BRASILEIRO E OS POTENCIAIS IMPACTOS AO MEIO AMBIENTE
}

\author{
Luciano Zanetti Pessoa Candiotto \\ Professor Doutor da UNIOESTE - Universidade Estadual do Oeste do Paraná \\ Fábio Alves de Vargas \\ Mestrando em Geografia pela Universidade Estadual do Oeste do Paraná - UNIOESTE \\ E-mail: engperitoambiental@gmail.com.
}

\section{Resumo}

A partir da edição do Novo Código Florestal brasileiro (Lei no 12.651/12), e mesmo desde sua tramitação como Projeto de Lei, verificou-se que as propostas de alteração ensejaram nos meios acadêmicos e científicos, e até mesmo na opinião pública, diversos embates quanto a um suposto retrocesso na efetivação da proteção ao meio ambiente, preconizado pela Constituição Federal de 1988. Tema controvertido no direito, o Código Florestal está sendo discutido há anos pelo Congresso Nacional, e nesse contexto, ruralistas e ambientalistas travam uma verdadeira batalha. $\mathrm{O}$ presente artigo analisa as principais alterações ocorridas no Código Florestal Brasileiro e a suas possíveis consequências. Levando em consideração a multidisciplinaridade do tema, realizou-se uma pesquisa bibliográfica visando à análise, confronto e síntese de conhecimentos já produzidos e publicados pelos estudiosos sobre o Código Florestal e suas alterações. Os resultados então obtidos nesse artigo permitem afirmar que as alterações legislativas no código florestal acarretam, indubitavelmente, impactos adversos ao meio ambiente, e consequentemente à sociedade. Entre eles, estão a diminuição generalizada das florestas e outros habitats; o comprometimento e a integridade dos atributos de Áreas de Preservação Permanentes e de Reservas Legais; e a relativização ao dever de reparar danos ambientais.

Palavras-chave: Meio ambiente. Novo Código Florestal. Impactos Ambientais.

\section{MAJOR CHANGES IN THE NEW BRAZILIAN FOREST CODE AND THE POTENTIAL IMPACTS TO THE ENVIRONMENT}

\begin{abstract}
Since the edition of the Brazilian New Forest Code (Law no. 12.651 / 12), and even since its drafting as a Bill, it has been verified that the proposals for alteration have brought about in the academic and scientific circles, and even in public opinion, several This is a controversial topic in law, the Forest Code has been discussed for years by the National Congress, and in this context, ruralists and environmentalists are fighting a real battle. This article analyzes the main changes that occurred in the Brazilian Forest Code and its possible consequences. Taking into account the multidisciplinary nature of the theme, a bibliographic research was carried out aiming at the analysis, comparison and synthesis of knowledge already produced and published by the scholars about the Forest Code and its changes. The results obtained in Recebido em 22/08/2018 / Aprovado para publicação em 04/10/2018.
\end{abstract}


this article allow us to affirm that the legislative changes in the forest code undoubtedly cause adverse impacts on the environment, and consequently on society. Among them are the widespread decline of forests and other habitats; the commitment and integrity of the attributes of Permanent Preservation Areas and Legal Reserves; and the relativization of the obligation to repair environmental damages.

Keywords: Environment. New Forest Code. Environmental impacts.

\section{Introdução}

Desde a Conferência de Estocolmo de 1972, primeira Conferência Mundial sobre Meio Ambiente e Desenvolvimento, promovida pela ONU, a maioria dos países tem se preocupado, ao menos na retórica, com a adoção de um modelo de desenvolvimento ecologicamente equilibrado. No Brasil, a instituição da Lei federal $n^{\circ}$ 6.938/81 (Política Nacional de Meio Ambiente) foi uma resposta à necessidade de evoluir em termos de proteção ao meio ambiente, em detrimento da tutela fragmentária e dispersa que vigorava até então.

Apesar da existência de diversas normativas legais para a conservação, preservação e uso sustentável do meio ambiente e de seus recursos, o Brasil continua sendo um país altamente degradador e permissivo em relação a questões ambientais. Infelizmente ainda são comuns casos flagrantes de exploração exacerbada e de desrespeito às normas ambientais.

Um dos principais exemplos dessa permissividade está na falta de cumprimento do antigo Código Florestal (Lei $n^{\circ} 4.771$ de 15 de setembro de 1965). Apesar de ser considerada uma lei ampla e que garantiria a manutenção de florestas e outras formas de vegetação natural em áreas consideradas fundamentais, como entornos de nascentes e margens de rios, a falta de aplicação adequada desta Lei gerou e autorizou processos de ocupação inadequados, que redundaram em outros problemas ambientais e sociais, em áreas urbanas e rurais. Foram cerca de 50 anos de descumprimento do Código Florestal (LEI $\mathrm{n}^{0}$ 4.771/65) e, apesar disso, o argumento de que seria necessária uma nova Lei para se adequar a realidade atual, foi amplamente utilizado para a aprovação do "novo" Código Florestal. Portanto, além da Lei no 4.771/65 não ter sido cumprida, demonstrando a falta de fiscalização e impunidade em relação a diversas normas brasileiras, ela foi questionada e considerada atrasada.

Apesar dessa evidência de descaso em relação ao cumprimento de normas no Brasil, especificamente da Lei $\mathrm{n}^{0} 4.771 / 65$, o Congresso Nacional (deputados federais e senadores) optou por criar uma lei mais flexível, pois assim, os inúmeros erros e negligências do passado seriam esquecidos e regulamentados, por meio da revogação do Código Florestal de 1965. 
Luciano Zanetti Pessoa Candiotto; Fábio Alves de Vargas

Assim, em 2012, o "novo" Código Florestal, através da Lei n ${ }^{0} 12.651 / 2012$ foi aprovado, abrindo mais um capítulo na triste história de impunidade e de favorecimentos que prevalece no Brasil. Contudo, tais alterações foram recepcionadas de maneira muito controvertida na sociedade brasileira. De um lado, a nova lei foi comemorada pelos chamados ruralistas (latifundiários e agricultores adeptos ao agronegócio) e seus representantes políticos (senadores, deputados, entre outros). De outro, uma substancial parcela da população, incluindo cientistas, alguns políticos e ambientalistas se manifestaram contrários à flexibilização ocorrida com a Lei $\mathrm{n}^{0} 12.651$, por considerarem o atual Código mais permissivo do que o anterior. Além disso, afirmam que tais modificações se deram sem o aval técnico da comunidade científica.

Baseado nos atuais pressupostos da interdisciplinaridade para a contribuição na produção do conhecimento em todos os campos da ciência, esta pesquisa objetiva verificar as discussões e argumentos científicos sobre os principais impactos adversos ao meio ambiente a partir das alterações legislativas do Novo Código Florestal, por meio da análise do panorama referente aos debates sobre as causas e consequências da Lei $\mathrm{n}^{0} 12.651 / 2012$ e de outras normas correlatas, com base em impressões por parte de cientistas e outros profissionais das áreas de ciências ambientais, humanas e ao Direito, através de pesquisas e opiniões sobre as alterações legais e o andamento dos instrumentos previstos na Lei.

De modo geral, esse artigo se justifica pelo fato de que as discussões até então postas em evidência sobre o assunto, costumam estar circunscritas aos meios jurídicos, carecendo de uma visão mais ampla, que pode ser discutida por pesquisadores de outras áreas do conhecimento, sobretudo dentro das ciências ambientais e humanas.

Os procedimentos metodológicos foram pautados em uma revisão bibliográfica acerca da temática, a qual tem o objetivo principal de apontar e analisar as implicações socioambientais que ocorreram e que podem ocorrer a partir da promulgação da Lei $n^{\circ} 12.651$ de 2012 (chamada popularmente de Novo Código Florestal brasileiro).

As principais normas analisadas foram a Lei $n^{0} 4.771 / 65$, a Lei $n^{0} 12.651 / 2012$ e a Lei $\mathrm{n}^{\mathrm{0}}$ 12.727/2012. Em termos de pesquisas e publicações científicas, destacam-se os trabalhos de Ab'Saber (2010); Barrela (2001); Buckup (1999; 2007); Casatti (2009; 2010); Develey e Pongiluppi (2010); Freitas (2010); Galetti et al. (2010); Lewinsohn e Prado (2005); Lewinsohn et al. (2010); Lowe-Mcconnell (1999); Marques et al. (2010); Metzger (2010); Rocha (2006); Ribeiro e Freitas (2010); Silva et al. (2011); Toledo et al. (2010); Tundisi e Tundisi (2010) entre outros. Também foram consultadas notícias, entrevistas e outros textos jornalísticos. 


\section{Alterações quanto às áreas de preservação permanente}

A definição legal das funções ecossistêmicas prestadas pelas Áreas de Preservação Permanente (APP) e pela Reserva Legal, constante no Código Florestal Brasileiro desde sua primeira edição em 1965 e mantida pela Lei $n^{\circ} 12.651$ de 2012, destaca claramente que ambas desempenham funções diversas e complementares. Notadamente, esses dois institutos são os que mais garantiriam a proteção florestal no Brasil. Por isso, faz-se mister uma imperiosa reflexão a respeito das mudanças ocorridas nos dispositivos que os regulam.

Um dos aspectos mais polêmicos do novo Código Florestal brasileiro diz respeito às normas para definição e delimitação das Áreas de Preservação Permanentes (APPs). Ao reduzir a dimensão destas áreas, que até então eram de, no mínimo, 30 metros em cada margem de curso d’água, há uma tendência de geração de impactos negativos à biodiversidade e à estabilidade de leitos e encostas fluviais.

Além dessa redução, outra mudança que implicará em perdas significativas de florestas no Brasil está na nova forma de medição para o estabelecimento das Áreas de Preservação Permanente às margens dos cursos d'água, que passam a serem medidas a partir da borda da calha do leito normal (regular) e, não mais a partir do leito maior (conforme era definido pela Lei ${ }^{\circ}$ 4.771/65). Isso levará a uma drástica redução em temos de exigência de APPs no Brasil.

Conforme o inciso I do artigo $4^{\circ}$ da Lei $n^{\circ} 12.651$ de 2012:

Art. 4. Considera-se Área de Preservação Permanente, em zonas rurais ou urbanas, para os efeitos desta Lei:

I - as faixas marginais de qualquer curso d'água natural perene e intermitente, excluídos os efêmeros, desde a borda da calha do leito regular, em largura mínima de (Incluído pela Lei n ${ }^{\circ} 12.727$, de 2012): (grifo nosso).

a) 30 (trinta) metros, para os cursos d'água de menos de 10 (dez) metros de largura;

b) 50 (cinquenta) metros, para os cursos d'água que tenham de 10 (dez) a 50 (cinquenta) metros de largura;

c) 100 (cem) metros, para os cursos d'água que tenham de 50 (cinquenta) a 200 (duzentos) metros de largura;

d) 200 (duzentos) metros, para os cursos d'água que tenham de 200 (duzentos) a 600 (seiscentos) metros de largura;

e) 500 (quinhentos) metros, para os cursos d'água que tenham largura superior a 600 (seiscentos) metros.

Tal forma de medição tem significativo impacto ambiental, importando em redução das áreas protegidas. Com efeito, no caso dos rios que apresentam substancial alteração de 
Luciano Zanetti Pessoa Candiotto; Fábio Alves de Vargas

seus leitos em períodos de cheias verificar-se-á que boa parte da APP será periodicamente inundada, prejudicando seus processos ecológicos essenciais, além da probabilidade de ocupação dessas áreas de várzea, provocando situações de risco e transtornos sociais às populações.

Ademais, tais áreas alagadas são biorreatores de processamento de matéria orgânica e estocagem temporária de nutrientes. De acordo com Casatti (2010), durante as águas baixas essas áreas recebem material alóctone (folhas, sementes, insetos) e trocam material com o curso d'água durante as cheias. Assim, a ausência dessas trocas pode afetar diretamente a produção de peixes, notadamente na fertilidade e consequentemente nas atividades de aquicultura e/ou piscicultura.

Sem perda de generalidade, tal mudança exclui toda a várzea de inundação anual dos rios, reduzindo sensivelmente a faixa de proteção em todos os rios brasileiros, independentemente de sua largura. Há assim uma tendência de perda de serviços ambientais fundamentais, como a dissipação de forças erosivas, recarga de aquíferos e o controle de enchentes (TUNDISI; MATSUMURA-TUNDISI, 2010).

Quanto aos reservatórios artificiais decorrentes de barramento de cursos d'água, a Lei $n^{\circ} 12.651$ de 2012 apresenta, por força do seu artigo $4^{\circ}$, inciso III, importante exceção às larguras mínimas para estabelecimento de suas APPs, as quais poderão ser definidas abaixo das legalmente definidas nos incisos I e II no momento da licença ambiental, bem como serão totalmente dispensadas caso o reservatório tenha menos de 1 (um) hectare, nos termos do $\S 4^{\circ}$ do mesmo artigo. ${ }^{1}$

Art. 4. [...]

III - as áreas no entorno dos reservatórios d'água artificiais, decorrentes de barramento ou represamento de cursos d'água naturais, na faixa definida na licença ambiental do empreendimento; [...]

$\S 4^{\circ}$ - Nas acumulações naturais ou artificiais de água com superfície inferior a 1 (um) hectare, fica dispensada a reserva da faixa de proteção prevista nos incisos II e III do caput, [...].

Essa permissão poderá suprimir locais propícios à reprodução e ao desenvolvimento de inúmeras espécies aquáticas, pois os reservatórios de águas naturais, mesmo aqueles com superfície inferior a 1 (um) hectare, servem para esse fim, significando prejuízo à proteção ambiental desses ecossistemas, conforme pontua estudo elaborado pelo Ministério Público do Estado de Minas Gerais².

No que tange a proteção de nascentes, as intermitentes foram excluídas:

Art. 4. Considera-se Área de Preservação Permanente, em zonas rurais ou urbanas, para os efeitos desta Lei: [...] 
Luciano Zanetti Pessoa Candiotto; Fábio Alves de Vargas

IV - as áreas no entorno das nascentes e dos olhos d'água perenes, qualquer que seja sua situação topográfica, no raio mínimo de 50 (cinquenta) metros; [...] (grifo nosso).

Conforme o inciso XVIII do artigo $3^{\circ}$ do Novo Código Florestal, os olhos d'água são afloramentos naturais do lençol freático, incluindo até mesmo os intermitentes. Eles são importantes para a alimentação de cursos d'água. Assim, a nova lei negou proteção aos olhos d'água intermitentes, que ficam vulneráveis às intervenções antrópicas, como a compactação do solo ao seu redor, a contaminação por fertilizantes, agrotóxicos ou outras substâncias.

Ainda que Áreas de Preservação Permanente sejam áreas territoriais especialmente protegidas, que devam ser preservadas e só utilizadas em situações excepcionais e inevitáveis, a Lei $\mathrm{n}^{\mathrm{o}} 12.651$ de 2012, pelo regramento contido em seu art. $8^{\circ}$, abre a possibilidade de intervenção e supressão de vegetação nativa em APP para situações em caso de utilidade pública.

De acordo com o inciso VIII do artigo $3^{\circ}$ do Novo Código Florestal, existe uma série de atividades consideradas de utilidade pública para fins de intervenção em APP, merecendo destaque a alínea $b$ desse inciso:

b) as obras de infraestrutura destinadas às concessões e aos serviços públicos de transporte, sistema viário, inclusive aquele necessário aos parcelamentos de solo urbano aprovados pelos Municípios, saneamento, gestão de resíduos, energia, telecomunicações, radiodifusão, instalações necessárias à realização de competições esportivas estaduais, nacionais ou internacionais, bem como mineração, exceto, neste último caso, a extração de areia, argila, saibro e cascalho [...] (grifo nosso).

Embora a maioria das atividades relacionadas nesse inciso tenham razões coerentes e justificativas plausíveis de intervenção em Áreas de Preservação Permanente, o mesmo não ocorre em relação a privilegiar atividades esportivas, ou pior ainda, permitir a intervenção em áreas ambientalmente frágeis para a gestão de resíduos, uma atividade potencialmente poluidora. Assim, não seria recomendado o desenvolvimento dessas atividades em áreas sensíveis como estas. ${ }^{3}$

A Lei $\mathrm{n}^{\mathrm{o}} 12.651$ de 2012 permite a continuidade de atividades ilegalmente instaladas em áreas ambientalmente protegidas, desde que anteriores a 22 de julho de 2008 para áreas rurais, e a 31 de dezembro de 2007 para áreas urbanas, definindo essas situações como áreas rural e urbana consolidadas, por meio dos incisos IV e XXVI do artigo $3^{\circ}$.

IV - área rural consolidada: área de imóvel rural com ocupação antrópica preexistente a 22 de julho de 2008, com edificações, benfeitorias ou atividades agrossilvipastoris, admitida, neste último caso, a adoção do regime de pousio; $[\ldots]$ 
Luciano Zanetti Pessoa Candiotto; Fábio Alves de Vargas

XXVI - área urbana consolidada: aquela de que trata o inciso II do caput do art. 47 da Lei n ${ }^{\circ} 11.977$, de 7 de julho de 2009.

O Novo Código Florestal permite tal consolidação, minimizando a recuperação de Áreas de Preservação Permanentes degradadas (artigos 61-A a 65), exigindo apenas uma pequena recuperação, da seguinte forma, conforme consigna Vallera e Ellovitch (2013, p. 9):

a) Nas APPs de cursos d'água na zona rural (art. 61-A e 61-B):

- imóvel com área de até 1 (um) módulo fiscal ${ }^{4}$ - deve recuperar 5 (cinco) metros de APP, desde que esta não ultrapasse $10 \%$ da área do imóvel.

- imóvel com área superior a 1 (um) até 2 (dois) módulos fiscais - deve recuperar 8 (oito) metros de APP, desde que esta não ultrapasse $10 \%$ da área do imóvel.

- imóvel com área superior a 2 (dois) até 4 (quatro) módulos fiscais - deve recuperar 15 (quinze) metros de APP, desde que esta não ultrapasse $20 \%$ da área do imóvel.

- imóvel com mais de 4 (quatro) até 10 (dez) módulos fiscais - deve recuperar 20 (vinte) metros para cursos d'água de até 10 (dez) metros.

- demais casos - deve recuperar área correspondente à metade da largura do curso d'água, em patamar mínimo de 30 (trinta) e máximo de 100 (cem) metros.

b) No entorno de lagos ou lagoas naturais (art. 61-A e 61-B):

- imóvel com área de até 1 (um) módulo fiscal - deve recuperar 5 (cinco) metros desde que a APP não ultrapasse $10 \%$ da área do imóvel.

- imóvel com área superior a 1 (um) e de até 2 (dois) módulos fiscais - deve recuperar 8 (oito) metros, desde que a APP não ultrapasse 10\% da área do imóvel.

- imóvel com área superior a 2 (dois) até 4 (quatro) módulos fiscais - deve recuperar 15 (quinze) metros, desde que a APP não ultrapasse $20 \%$ da área do imóvel.

- imóvel com área superior a 4 (quatro) módulos fiscais - deve recuperar 30 (trinta) metros.

c) No entorno de nascentes - deve recuperar 15 (quinze) metros.

d) Na zona urbana "ao longo dos rios ou de qualquer curso d'água, será mantida faixa não edificável com largura mínima de 15 (quinze) metros de cada lado" (art. 65, $\S 2^{\circ}$ ).

O módulo fiscal serve de parâmetro para a classificação fundiária dos imóveis rurais dos municípios quanto ao seu tamanho, em conformidade com o art. $4^{\circ}$ da Lei $n^{\text {o }}$ 8.629/93 (BRASIL, 1993). De acordo com essa lei, as propriedades rurais podem ser classificadas em:

- Minifúndios: com tamanho de até um módulo fiscal;

- Pequenas propriedades: com área entre um e quatro módulos fiscais;

- Médias propriedades: com dimensão superior a quatro até 15 módulos fiscais e

- Grandes propriedades: com área maior do que 15 módulos fiscais.

A dimensão de um módulo fiscal varia de acordo com o município onde está localizada a propriedade. O valor do módulo fiscal no Brasil varia de 5 a 110 hectares, ou seja, ao mesmo tempo em que há municípios com enquadramento de pequena propriedade rural medindo 20 hectares, existem aqueles que chegam a medir 440 hectares. A figura 1 apresenta o tamanho dos módulos fiscais no Brasil. 
Figura 1 - Tamanho dos Módulos Fiscais no Brasil.

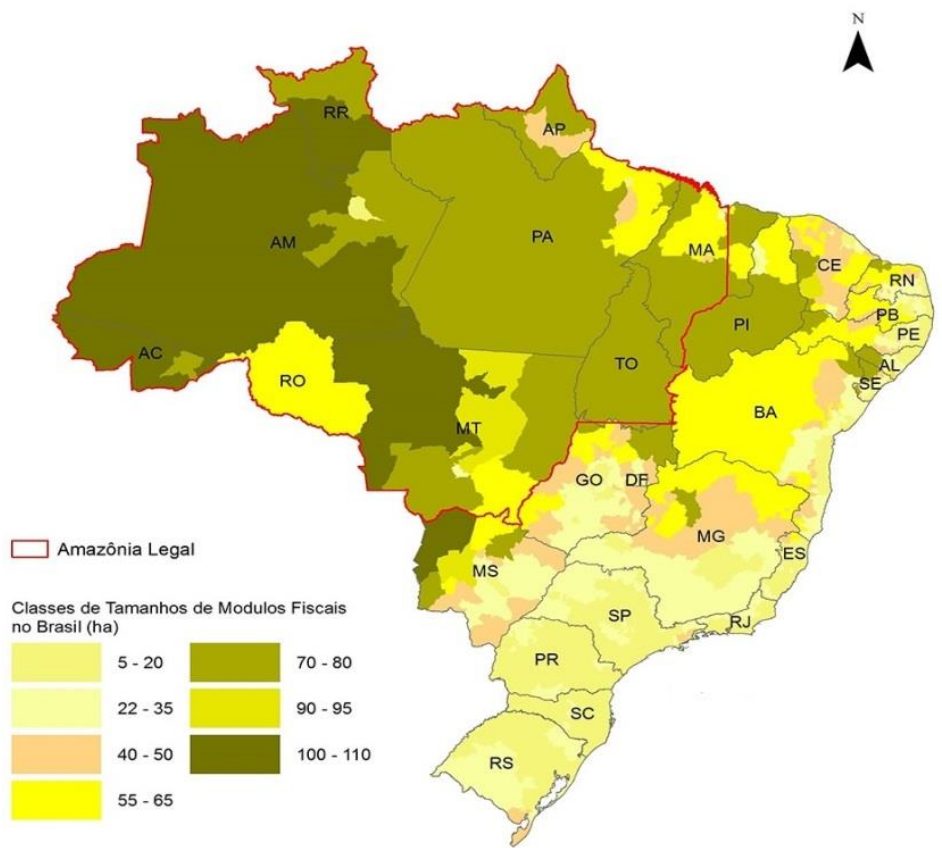

Fonte: Landau et al. (2012).

Por sua vez, o art. $3^{\circ}$, I ao IV, da Lei $\mathrm{n}^{\circ} 11.326 / 2006$ caracteriza aqueles que se enquadram entre os agricultores familiares e empreendedores familiares rurais: é todo aquele que pratica atividades no meio rural, atendendo aos seguintes requisitos, simultaneamente: (a) não detenha área maior que quatro módulos fiscais; (b) utilize predominantemente mão de obra da própria família nas atividades econômicas relacionadas ao seu empreendimento; (c) tenha percentual mínimo da renda familiar originada de atividades econômicas do seu empreendimento; e (d) dirija seu empreendimento com sua família. (grifo nosso).

Nesse contexto, fica difícil imaginar o cumprimento dos requisitos supramencionados em propriedades que detenham determinados tamanhos (50 a 440 hectares, por exemplo). Isso pode ser considerada uma lacuna, porquanto parece um tanto quanto inapropriado essa atual classificação, pois generaliza e impõe certa subjetividade ao conceito de propriedade familiar. Seria coerente enquadrar um estabelecimento agropecuário de 440 hectares como representante da agricultura familiar?

Um grave problema nesse caso é que houve um substancial aumento nas dimensões das propriedades classificadas como pequenas, comparando-se com o antigo código florestal (Lei $\left.{ }^{\circ} 4.771 / 1965\right)$, o qual em seu art. $1^{\circ}, \S 2^{\circ}$, I, estabelecia que:

Pequena propriedade ou posse rural familiar: aquela explorada mediante o trabalho pessoal do proprietário ou posseiro e de sua família, admitida a ajuda eventual de terceiro e cuja renda bruta seja proveniente, no mínimo, 
em oitenta por cento, de atividade agroflorestal ou do extrativismo, cuja área não supere:

a) cento e cinquenta hectares se localizada nos Estados do Acre, Pará, Amazonas, Roraima, Rondônia, Amapá e Mato Grosso e nas regiões situadas ao norte do paralelo 13o S, dos Estados de Tocantins e Goiás, e ao oeste do meridiano de 44o W, do Estado do Maranhão ou no Pantanal matogrossense ou sul-mato-grossense;

b) cinquenta hectares, se localizada no polígono das secas ou a leste do Meridiano de $44^{\circ} \mathrm{W}$, do Estado do Maranhão; e

c) trinta hectares, se localizada em qualquer outra região do País (grifo nosso).

Essa alteração levará a um déficit enorme em termos de recuperação e recomposição em áreas de proteção, pois mais propriedades estarão isentas de recuperação florestal. Nesse novo Código Florestal, o tamanho dos módulos fiscais passou a ter maior relevância como parâmetro legalmente importante para a classificação fundiária das propriedades rurais e indicação de seus enquadramentos para efeito de recuperações e recomposições. Ocorre que essa flexibilização pode implicar prejuízos para que as APPs desempenhem suas funções ecológicas essenciais. Uma APP de poucos metros não serve para preservar de maneira satisfatória a qualidade dos recursos hídricos, a estabilidade geológica, não facilita o fluxo gênico de fauna e flora, como previsto no artigo $3^{\circ}$ da própria lei ${ }^{5}$. Muitas espécies usam essas faixas como corredores de dispersão, o que faz destas áreas importantes elementos de conexão entre fragmentos remanescentes de matas.

\section{Alterações quanto à reserva legal}

Muito embora o Novo Código Florestal brasileiro lance, em seu artigo 12, comando no sentido da obrigatoriedade de manutenção de área de vegetação nativa a título de Reserva Legal, essa mesma codificação ambiental excepciona tal regra, dispensando a existência da Reserva Legal, nos termos dos $\S \S 6^{\circ}, 7^{\circ}$ e $8^{\circ}$ do artigo em comento:

$\S 6^{\circ}$ - Os empreendimentos de abastecimento público de água e tratamento de esgoto não estão sujeitos à constituição de Reserva Legal.

$\S 7^{\circ}$ - Não será exigido Reserva Legal relativa às áreas adquiridas ou desapropriadas por detentor de concessão, permissão ou autorização para exploração de potencial de energia hidráulica, nas quais funcionem empreendimentos de geração de energia elétrica, subestações ou sejam instaladas linhas de transmissão e de distribuição de energia elétrica.

$\S 8^{\circ}$ - Não será exigido Reserva Legal relativa às áreas adquiridas ou desapropriadas com o objetivo de implantação e ampliação de capacidade de rodovias e ferrovias. 
Luciano Zanetti Pessoa Candiotto; Fábio Alves de Vargas

A partir do rol de exceções trazidas pelos parágrafos acima transcritos, vislumbra-se questionável priorização desequilibrada do necessário desenvolvimento econômico em detrimento da proteção ambiental. ${ }^{6}$

Nessa mesma perspectiva, o artigo 67 da Lei $\mathrm{n}^{\circ} 12.651$ de 2012 dispensa a recuperação de Reserva Legal degradada em imóveis de até 4 (quatro) módulos fiscais. ${ }^{7}$

Art. 67. Nos imóveis rurais que detinham, em 22 de julho de 2008, área de até 4 (quatro) módulos fiscais e que possuam remanescente de vegetação nativa em percentuais inferiores ao previsto no art. 12, a Reserva Legal será constituída com a área ocupada com a vegetação nativa existente em 22 de julho de 2008, vedadas novas conversões para uso alternativo do solo.

Os percentuais de Reserva Legal em cada propriedade são definidos no artigo 12 da Lei $\mathrm{n}^{\circ} 12.651$ de 2012

Art. 12. Todo imóvel rural deve manter área com cobertura de vegetação nativa, a título de Reserva Legal, sem prejuízo da aplicação das normas sobre as Áreas de Preservação Permanente, observados os seguintes percentuais mínimos em relação à área do imóvel, excetuados os casos previstos no art. 68 desta Lei:

I - localizado na Amazônia Legal:

a) $80 \%$ (oitenta por cento), no imóvel situado em área de florestas;

b) $35 \%$ (trinta e cinco por cento), no imóvel situado em área de cerrado;

c) $20 \%$ (vinte por cento), no imóvel situado em área de campos gerais;

II - localizado nas demais regiões do País: $20 \%$ (vinte por cento).

Assim, a reserva legal será constituída com o percentual de vegetação nativa existente em 22 de julho de 2008. Ou seja, a lei permite o registro de Reservas Legais em percentual inferior a $20 \%$ da área do imóvel, consolidando os desmatamentos que ocorreram ilicitamente. Evidencia-se dessa forma uma afronta ao princípio da isonomia em relação aos que preservaram, demarcaram e averbaram suas Reservas Legais.

Destaca-se, ainda, que as propriedades com área de até 4 (quatro) módulos fiscais correspondem a cerca de $90 \%$ dos imóveis rurais do Brasil, o que corresponderia a uma grande quantidade de áreas isentas de recuperação. ${ }^{8}$ Além disso, dependendo do Estado da Federação, um módulo fiscal pode ultrapassar 100 hectares.

De acordo com o $\S 3^{\circ}$ do artigo 66 do Novo Código Florestal, é permitido recompor a Reserva Legal com espécies exóticas, ${ }^{9}$

I - recompor a Reserva Legal; $[\ldots]$

$\S 3^{\circ}$ - A recomposição de que trata o inciso I do caput poderá ser realizada mediante o plantio intercalado de espécies nativas com exóticas ou frutíferas, em sistema agroflorestal, observados os seguintes parâmetros:

I - o plantio de espécies exóticas deverá ser combinado com as espécies nativas de ocorrência regional;

II - a área recomposta com espécies exóticas não poderá exceder a 50\% (cinquenta por cento) da área total a ser recuperada. 
Luciano Zanetti Pessoa Candiotto; Fábio Alves de Vargas

Segundo Lewinsohn et al. (2010, p. 7), em artigo produzido para o Programa BiotaFapesp, espécies exóticas são uma grande causa de perda de biodiversidade nos ecossistemas, ipsis litteris: "A introdução de espécies exóticas de interesse econômico desvirtua a função das Reservas Legais, pois prejudica a conservação de espécies em vez de estimular a exploração sustentável de espécies nativas".

Existem formas de manejo agroflorestal que utilizam a introdução de espécies exóticas. Contudo, sua função é alimentar ou para geração de biomassa e seu manejo deve ser criterioso, para evitar que essas espécies exóticas se tornem espécies invasoras. Assim, a introdução de espécies exóticas em Reservas Legais deveria ser melhor detalhada na legislação, para evitar abusos na interpretação do $\S 3^{\circ}$ do artigo 66.

Embora as funções ecossistêmicas da Área de Preservação Permanente e da Reserva Legal não se confundam, o novo Código Florestal permite, em casos excepcionais, o cômputo da área de APP no percentual de Reserva Legal.
Art. $16[\ldots]$
$\S 6^{\circ}$ - Será admitido, pelo órgão ambiental competente, o cômputo das áreas relativas à vegetação nativa existente em área de preservação permanente no cálculo do percentual de reserva legal, desde que não implique em conversão de novas áreas para o uso alternativo do solo, e quando a soma da vegetação nativa em área de preservação permanente e reserva legal exceder a:
I - oitenta por cento da propriedade rural localizada na Amazônia Legal;
II - cinquenta por cento da propriedade rural localizada nas demais regiões do País; e
III - vinte e cinco por cento da pequena propriedade definida elas alíneas " $b$ " e "c" do inciso I do $\S 2^{\circ}$ do art. $1^{\circ}$.

Esse cálculo combinado não faz sentido, pois além de abrigarem diferentes espécies, a APP e a Reserva Legal possuem funções distintas. Enquanto as APPs protegem áreas frágeis e desempenham importante papel na conservação da biodiversidade, a Reserva Legal, além da conservação da biodiversidade, objetiva o uso sustentável de recursos naturais, conforme já definido a priori pelo artigo $3^{\circ}$ do novo código.

A Lei n. ${ }^{\circ} 12.651$ de 2012 em seu artigo 18, $\S 4^{\circ}$ desobriga a averbação da Reserva Legal no Registro de Imóveis depois de inscrita no Cadastro Ambiental Rural (CAR),

Art. $18[\ldots]$

$\S 4^{\circ}-\mathrm{O}$ registro da Reserva Legal no CAR desobriga a averbação no Cartório de Registro de Imóveis, sendo que, no período entre a data da publicação desta Lei e o registro no CAR, o proprietário ou possuidor rural que desejar fazer a averbação terá direito à gratuidade deste ato.

Essa desobrigação não é coerente com o princípio de não retrocesso que norteia o direito ambiental, porquanto, o registro do imóvel rural em cartório, com todos os dados a ele inerentes, especialmente acerca das áreas ambientais protegidas, respeita os princípios da 
Luciano Zanetti Pessoa Candiotto; Fábio Alves de Vargas

publicidade, trazendo ao seu proprietário a eficácia de seu direito perante terceiros e à sociedade, bem como segurança jurídica quanto à identificação e destinação desses bens ambientais. Assim, desconsiderar a importância desse procedimento ao torná-lo facultativo é certamente um retrocesso (LEHFELD; CARVALHO; BALBIM, 2013).

O PRA (Programa de Regularização Ambiental) é uma norma ambiental inserida no ordenamento jurídico pelo artigo 59 do Novo Código Florestal Brasileiro, cuja aplicabilidade ainda depende de decreto regulamentar pelo Executivo Federal para implantação do referido Programa. No entanto, na hipótese de implantação surgiria, conforme pontuam Valera e Ellovitch (2013, p. 5), "uma ampla anistia a infrações administrativas e crimes ambientais".

$\S 4^{\circ}$ - No período entre a publicação desta Lei e a implantação do PRA em cada Estado e no Distrito Federal, bem como após a adesão do interessado ao PRA e enquanto estiver sendo cumprido o termo de compromisso, o proprietário ou possuidor não poderá ser autuado por infrações cometidas antes de 22 de julho de 2008, relativas à supressão irregular de vegetação em Áreas de Preservação Permanente, de Reserva Legal e de uso restrito.

$\S 5^{\circ}$ - A partir da assinatura do termo de compromisso, serão suspensas as sanções decorrentes das infrações mencionadas no $\S 4^{\circ}$ deste artigo e, cumpridas as obrigações estabelecidas no PRA ou no termo de compromisso para a regularização ambiental das exigências desta Lei, nos prazos e condições neles estabelecidos, as multas referidas neste artigo serão consideradas como convertidas em serviços de preservação, melhoria e recuperação da qualidade do meio ambiente, regularizando o uso de áreas rurais consolidadas conforme definido no PRA.

Conforme se verifica nos $\S \S 4^{\circ}$ e $5^{\circ}$ do art. 59 do código em análise, restam proibidas as autuações administrativas por infrações cometidas até 22 de julho de 2008, bem como suspensas as multas aplicadas a proprietários inscritos no Programa de Regularização Ambiental (PRA) por infrações cometidas no referido período, no caso de o degradador cumprir um termo de compromisso com o órgão ambiental, extinguindo-se, por conseguinte a penalidade administrativa.

Nesse mesmo sentido, adentrando-se na área criminal, o artigo 60 do novo Código Florestal estende tal anistia à responsabilidade penal relativa aos crimes dos artigos 38, 39 e 48 da Lei ${ }^{\circ}$ 9.605/98, cometidos até 22 de julho de 2008, na hipótese de o infrator assinar o Termo de Compromisso de Regularização, suspendendo-se a punibilidade e o prazo prescricional, sendo que o seu devido cumprimento extinguiria a punibilidade.

Art. 60. A assinatura de termo de compromisso para regularização de imóvel ou posse rural perante o órgão ambiental competente, mencionado no art. 59, suspenderá a punibilidade dos crimes previstos nos arts. 38, 39 e 48 da Lei ${ }^{\circ}$ 9.605 , de 12 de fevereiro de 1998, enquanto o termo estiver sendo cumprido. $\S 1^{\circ}$ - A prescrição ficará interrompida durante o período de suspensão da pretensão punitiva. 
Luciano Zanetti Pessoa Candiotto; Fábio Alves de Vargas

$\S 2^{\circ}$ - Extingue-se a punibilidade com a efetiva regularização prevista nesta Lei.

Assim, o Novo Código Florestal Brasileiro flexibilizou instrumentos de proteção. Medidas como essas tendem a incentivar ainda mais o desmatamento, gerando claros impactos negativos sobre a biodiversidade brasileira, notadamente por meio da redução e fragmentação ainda mais intensa da vegetação nativa remanescente.

Segundo Lewinsohn et al. (2010), diversas consequências são esperadas, como por exemplo, a extinção de espécies de muitos grupos de plantas, animais vertebrados e invertebrados; o aumento de emissão de $\mathrm{CO}_{2}$; a redução de uma série de serviços ambientais (controle de pragas, polinização, recursos madeireiros e não madeireiros, e proteção de recursos hídricos são alguns exemplos); a propagação de doenças; e a intensificação de outras perturbações como incêndios, caça, extrativismo exploratório, assoreamentos com implicações diretas no abastecimento de água e energia.

\section{Manifestações científicas acerca das alterações legislativas do novo código florestal}

A Academia Brasileira de Ciências (ABC) e a Sociedade Brasileira para o Progresso da Ciência (SBPC), representando a comunidade científica na participação da reformulação do Código Florestal, manifestaram-se de maneira efetiva, formando um grupo de trabalho (GT) em 2010. Esse trabalho ${ }^{10}$ ofereceu dados e argumentos técnico-científicos para subsidiar as discussões em torno das mudanças propostas pelo Congresso Nacional.

Além dessas entidades, participaram desse GT diversas instituições de pesquisa, universidades, entidades de classes e organizações civis. Essas instituições concordaram com a necessidade de reforma no Código Florestal, a fim de adaptá-lo a realidade nos usos e ocupações do solo em território nacional. Entretanto, afirmam que essa atualização deveria ser realizada à luz da ciência e da tecnologia. A partir do trabalho do GT foram emitidas cartas e relatórios, encaminhadas aos Deputados Federais e Senadores, e divulgados em nível nacional. Tais documentos apresentaram uma síntese dos trabalhos realizados pelo GT e abordaram os seguintes temas:

- Uso agrícola do território nacional: potencialidades e desafios da estrutura legislativa brasileira;

- Perdas de solos e água decorrentes do uso da terra: a erosão e seu impacto;

- Os impactos do código florestal sobre a biodiversidade; 
- A importância das Áreas de Preservação Permanente e de Reserva Legal no imóvel rural, incluindo os benefícios ambientais e econômicos dessas áreas de proteção;

De maneira resumida, os trabalhos do GT, sintetizavam que: indubitavelmente, há uma relação estreita entre a composição da flora e da fauna, e também que a diversidade biológica possui distribuição espacial muito heterogênea. Esses dados alertam sobre os riscos potenciais de reduções do conjunto da vegetação nativa presente nas APPs e RLs.

A preservação das florestas é fundamental para se manter os serviços ambientais (regime e qualidade da água; prevenção da erosão e do assoreamento; amortecimento de enchentes; conservação da biodiversidade, etc.), notadamente aqueles relacionados com o regime hídrico. Por isso, a SBPC e a $\mathrm{ABC}$ recomendaram que:

Todas as Áreas de Proteção Permanente de beira de curso d'água devem ter sua vegetação preservada e naquelas em que essa vegetação foi degradada elas devem ser integralmente restauradas;

Deve ser mantida a definição de APP de cursos d'água do Código Florestal atual ("...desde o seu nível mais alto em faixa marginal..."(Art. $2^{\circ}$, a) redação dada pela Lei n. $^{\circ} 7.803$ de 18.7.1989);

A situação existente entre o menor e o maior leito sazonal (as várzeas, os campos úmidos, as florestas paludícolas e outras) deve receber na lei, o mesmo status de proteção das APPs;

Os usos ribeirinhos das APPs na Amazônia devem receber tratamento diferenciado no Código Florestal, de forma a respeitar a cultura agrícola local e preservar a agricultura de vazante e a produção de várzea, já que se caracterizam como de baixo impacto ambiental;

A definição dos limites das APPs nas áreas úmidas deve ser calculada a partir do nível mais alto da cheia conforme definição da Convenção de Ramsar (Convenção sobre Zonas Úmidas de Importância Internacional) (SBPC; ABC, 2011, p. 1).

Em relação às Áreas Rurais Consolidadas em APPs, a comunidade científica por meio da SBPC e da ABC, consideraram que tal instrumento é um equívoco, pois não há justificativa para adotar a data de 22 de julho de 2008 para anistiar as propriedades em desacordo com a legislação.

O termo área rural consolidada representa, na prática, o uso consolidado das áreas de preservação permanente, o que dispensaria a aplicação da legislação ambiental, garantindo a continuidade de uso agrícola dessas áreas e ignorando os serviços ambientais das APPs nessas áreas de uso consolidadas. Além de impedir a continuidade do uso agrícola das APPs, a legislação deve explicitar a necessidade de ações de restauração integral dessas áreas, para o cumprimento desses serviços (SBPC; ABC, 2011, p. 2).

Os diferentes biomas nacionais são responsáveis pela biodiversidade do país. No cerrado, por exemplo, estão descritas mais de 12.000 espécies (MENDONÇA et al., 1998 apud SILVA et al., 2011). Fitofisionomias brasileiras, como a Mata Atlântica, possui 
Luciano Zanetti Pessoa Candiotto; Fábio Alves de Vargas

potencial econômico até mesmo em ações de restauração. Contudo, faz-se necessário para o uso sustentável das espécies e paisagens dos biomas um melhor ordenamento e gestão do território, assim como valorizar e manejar os recursos e recuperar áreas degradadas (SILVA et al., 2011).

Existem evidências de que o clima global é regulado pela biosfera, ou seja, pelo funcionamento integrado dos ecossistemas naturais (KLEIDON, 2004 apud SILVA et al., 2011). Na Amazônia, vários trabalhos evidenciam mecanismos reguladores do clima proporcionados pela floresta, como na promoção de chuvas por meio de sementes biogênicas de nuvens ou no bombeamento ativo da umidade atmosférica para dentro da América do Sul desde o Atlântico equatorial (PÖSCHL et al., 2010 apud SILVA et al., 2011).

O desmatamento continuado tem sido associado a alterações no regime de chuvas. (MARENGO et al., 2004 apud SILVA et al., 2011) descrevem rios atmosféricos de vapor que ligam a capacidade hidrológica da floresta amazônica às chuvas que irrigam regiões produtivas na América do Sul.

Outros trabalhos encontraram correlação entre limites mínimos de pluviosidade, os quais, se ultrapassados, podem inviabilizar a continuidade da floresta amazônica como tal (NOBRE et al., 2009).

Heckenberger et al., 2008 apud Silva et al. (2011), em um estudo paleontológico, revelou que sociedades pré-colombianas que habitaram a região do rio Xingu atingiram elevado grau de urbanismo, com acentuada manipulação do ambiente, o qual incluía agricultura, estradas e barragens, sem, contudo gerar grandes desmatamentos. A supressão de APPs e RLs na mesma região no Mato Grosso implicou em diversas consequências adversas (SILVA et al., 2011).

Silva et al. (2011) também asseveram que a presença de vegetação protetora em áreas sensíveis, como é o caso de APPs e RLs, aumenta a estruturação do solo e, consequentemente a permeabilidade, o que implica maior amortecimento do aporte e de infiltração de água, proporcionando a recarga lenta de aquíferos.

Com maior infiltração vertical no topo do morro, menor quantidade de água escoará pela superfície ao longo das encostas de jusante, aumentando sua estabilidade. Tanto um efeito quanto o outro são importantes para a integridade geológica das encostas. Os deslizamentos do vale do rio Itajaí em 2008 e na zona serrana do Rio de Janeiro em 2011 têm ligação importante com o estado de conservação da vegetação natural nos topos de morros, nas encostas e mesmo nos sopés. A especificidade da fragilidade destas áreas ao excesso de água resulta da combinação de muitos e heterogêneos fatores, como aqueles ligados à geologia, à geomorfologia e 
Luciano Zanetti Pessoa Candiotto; Fábio Alves de Vargas

aos solos, nem todos previstos ou logicamente enquadrados pela legislação florestal (SILVA et al, 2011, p. 69).

O Código Florestal possui parâmetros mínimos de proteção, ainda insuficientes para proteger a vegetação nativa de maneira cientificamente substanciada. Além da questão da biodiversidade e dos serviços ambientais, a vegetação nativa remanescente tem importante papel para diminuir o isolamento dos fragmentos maiores de vegetação, atuando como "trampolins ecológicos" nos deslocamentos de espécies pela paisagem.

A SBPC e a ABC afirmam que as alterações do Código Florestal devem ser efetuadas sob a luz da ciência e dos conhecimentos técnicos adquiridos. Nesse sentido, sugeriram algumas premissas ${ }^{11}$ básicas para a consolidação de alterações sob a ótica de um ordenamento territorial adequado e justo, a saber:

A) Necessidade de uma fundamentação participativa, consensual a todos os setores diretamente envolvidos com a temática.

B) Obrigatoriedade de as proposições realizadas estarem fundamentadas no conhecimento científico sobre o respectivo tema.

C) Fundamentação amparada por uma visão plural e propositiva, a qual integre o meio rural e o meio urbano, respeitando-se as particularidades ambientais de cada bioma, dentro do conceito de ordenamento territorial e planejamento da paisagem, utilizando os recursos avançados de imageamento e de modelagem computacional de terrenos.

D) Fundamentação na visão integrada da propriedade rural, dentro da perspectiva de sua adequação ambiental, considerando as áreas de produção agrícola, as áreas de preservação e uso misto.

E) A adequação tecnológica na ocupação de áreas agrícolas deverá ser feita com base na sua aptidão, visando potencializar a produtividade com o menor impacto ambiental possível.

F) O conceito principal deverá ser o da construção de uma legislação ambiental estimuladora de boas práticas e garantidora do futuro e que proporcione a construção de paisagens rurais com sustentabilidade social, ambiental e econômica.

Assim, é possível perceber que as ponderações científicas constantes nos documentos citados deveriam servir como subsídio para os tomadores de decisão que atuaram na reformulação do Novo Código Florestal. Assim, a comunidade científica se fez presente nesse embate e não se calou. Contudo, os alertas dos cientistas não foram levados em consideração pelos políticos.

Aziz ab'sáber e sua defesa por um código da biodiversidade 
Luciano Zanetti Pessoa Candiotto; Fábio Alves de Vargas

Entre os diversos cientistas que se posicionaram contra determinadas alterações do Código Florestal brasileiro, destaca-se o geógrafo da USP, Aziz Ab'Sáber. Em um artigo publicado em 2010, que foi alvo de circulação em jornais e outros veículos da mídia, Ab'Sáber (2010) alertava que qualquer tentativa de mudança no Código Florestal deve, obrigatoriamente, levar em conta: a dimensão continental de nosso território; os macro biomas e os mini biomas; as faixas de transição e relictos de ecossistemas. Além disso, tais propostas de mudanças deveriam ser conduzidas por pessoas comprovadamente qualificadas, e segundo ele, "bioeticamente" sensíveis.

Sua crítica descreve que o primeiro grande erro na revisão do Código Florestal foi a "estadualização" dos "fatos ecológicos" específicos. Segundo ele, isso exige uma integração de órgãos federais específicos com órgãos estaduais e municipais também específicos, assim como a necessidade de criação de uma Polícia Federal Rural para atuar em parceria com o Exército brasileiro. Assim, Em oposição à estadualização, deveríamos focar no zoneamento físico e ecológico de todos os morfo-domínios do país, que seriam.

[...] as duas principais faixas de Florestas Tropicais brasileiras: a zonal amazônica e a zonal das matas atlânticas o domínio dos cerrados, cerradões e campestres; a complexa região semiárida dos sertões nordestinos; os planaltos de araucárias e as pradarias mistas do Rio Grande do Sul, além de nosso litoral e o Pantanal Mato-grossense (AB'SÁBER, 2010, p. 332).

Para esse autor, faz-se necessário enfocar as alterações em diretrizes que considerem as grandes regiões naturais do país, notadamente domínios de natureza distintos entre si, como por exemplo, a Amazônia e suas extensas florestas tropicais, e o Nordeste seco, com seus diferentes tipos de caatingas, vez que tais regiões são distintas em relação à físionomia e à ecologia, bem como suas condições socioambientais.

Ab’Sáber destacava a falta de conhecimento dos revisores do Código Florestal sobre a ordem de grandeza das redes hidrográficas ao estabelecerem medidas genéricas de proteção para faixas de APPs em beira de rios.

Na linguagem amazônica tradicional, o próprio povo já reconheceu fatos referentes à tipologia dos rios regionais. Para eles, ali existem, em ordem crescente: igarapés, riozinhos, rios e parás. Uma última divisão lógica e pragmática, que é aceita por todos os que conhecem a realidade da rede fluvial amazônica (AB'SÁBER, 2010, p. 332). 
Luciano Zanetti Pessoa Candiotto; Fábio Alves de Vargas

Igualmente, julga que a ideia de reduzir as faixas de proteção de florestas ripárias tem um caráter extremamente genérico de aplicação duvidosa. Em sua visão não é possível limitar generalizadamente as áreas beiradeiras, em termos de metros de largura.

O autor também critica radicalmente os atuais percentuais estabelecidos destinados às Áreas de Reserva Legal.

[...] ninguém tem a coragem de analisar o que aconteceu nos espaços ecológicos de São Paulo, Paraná, Santa Catarina, e Minas Gerais com o percentual de 20\%. Nos planaltos interiores de São Paulo a somatória dos desmatamentos atingiu cenários de generalizada derruição. Nessas importantes áreas, dominadas por florestas e redutos de cerrados e campestres, somente o tombamento integrado da Serra do Mar, envolvendo as matas atlânticas, os solos e as aguadas da notável escarpa, foi capaz de resguardar os ecossistemas orográficos da acidentada região. O restante, nos "mares de morros", colinas e várzeas do Médio Paraíba e do Planalto Paulistano, e pró-parte da Serra da Mantiqueira, sofreram uma derruição deplorável. É o que alguém no Brasil - falando de gente inteligente e bioética - não quer que se repita na Amazônia brasileira, em um espaço de 4.200.000 km² (AB'SÁBER, 2010, p. 333).

Ab'Sáber também alertava para o fato que a permissividade na supressão de florestas do Novo Código Florestal implicará um mosaico caótico de áreas desmatadas e faixas inter propriedades estreitas e mal preservadas. Lembrava ainda que, propriedades de até 440 hectares não têm a obrigatoriedade de recuperar a vegetação a título de Reserva Legal, o que a médio e longo prazo provocaria um caleidoscópio no espaço total de áreas da Amazônia. Isso prejudicaria a biodiversidade local.

Para Ab'Sáber, ser conivente com a liberação de processos de desmatamento:

Significa desconhecer a progressividade de cenários bióticos, a diferentes espaços de tempo futuro. Favorecendo de modo simplório e ignorante os desejos patrimoniais de classes sociais que só pensam em seus interesses pessoais, no contexto de um país dotado de grandes desigualdades sociais. Cidadãos de classe social privilegiada, que nada entendem de previsão de impactos. Não tem qualquer ética com a natureza. Não buscam encontrar modelos técnico-científicos adequados para a recuperação de áreas degradadas, seja na Amazônia, seja no Brasil Tropical Atlântico, ou alhures (AB'SÁBER, 2010, p. 332).

Em relação à inovação conceitual acerca de pequena propriedade rural, Ab'Sáber afirma que propriedades com 400 hectares nunca deveriam ser incluídas nessa categoria.

O fato de considerar o espaço de propriedades familiares até o nível de 400 ha é um absurdo total. Trata-se de uma excessiva flexibilização que poderá produzir um mosaico derruidor de florestas ao longo de rodovias, estradas, riozinhos e igarapés. Um cenário trágico para o futuro, em processo no interior da Amazônia brasileira (AB'SÁBER, 2010, p. 334). 
Luciano Zanetti Pessoa Candiotto; Fábio Alves de Vargas

Para Ab’Sáber as alterações do Novo Código Florestal deveriam contemplar não só a presente geração, mas as suas consequências no decorrer de um largo tempo, vez que isso é uma questão de bioética com o futuro.

O autor relembra que nossas florestas têm relação com o clima do planeta, assunto que preocupa diversos pesquisadores pelo mundo afora. Pessoas essas que esperam que o Brasil proteja de maneira adequada a vegetação florestal que ainda resta em regiões equatoriais e subequatoriais do mundo.

Em relação a alterações no Código Florestal, Ab’Sáber apontava para a necessidade de se pensar no território do país como um todo, sob a ótica de um ampliado e assertivo Código de biodiversidade, isto é, um pensamento que envolva integradamente as necessidades de proteção às grandes florestas (Amazônia e Matas Tropicais Atlânticas); ao domínio de caatingas e agrestes sertanejos; aos planaltos centrais com cerrados, cerradões e campestres; aos planaltos de araucárias sul-brasileiros; às pradarias mistas do Rio Grande do Sul; aos redutos e mini biomas litorâneos e do Pantanal mato-grossense e faixas de transição de todos os domínios morfoclimáticos e fitogeográficos brasileiros.

\section{Interferências esperadas na dinâmica da paisagem}

\section{Fragmentação Florestal e Efeito de Borda}

A fragmentação florestal está atrelada como um dos principais fatores que ameaçam a biodiversidade (SAUNDERS; HOBBS; MARGULES, 1991).

A fragmentação florestal ocorre em virtude da descontinuidade da cobertura florestal. Ela pode ocorrer de forma natural ou antrópica, interferindo negativamente na passagem de animais, pólen ou sementes. Os principais fatores analisados na fragmentação são a borda, o tipo de vizinhança, o grau de isolamento e o tamanho dos fragmentos (VIANA; TABANEZ; MARTINS, 1992). Segundo Forman e Godron (1986), bordas são regiões limites entre uma paisagem natural específica e o seu entorno. Essas regiões sofrem influências que impedem as condições ideais para as espécies que vivem no interior da área.

As áreas fragmentadas apresentam mudanças microclimáticas e uma variação no regime de luz em seu interior. Elas começam a receber sementes de plantas que se adaptam a ambientes perturbados, prejudicando espécies nativas, alterando a composição e estrutura do remanescente (TABARELLI; LOPES; PERES, 2008). Apesar de as espécies possuírem uma tolerância a fatores físicos e biológicos, elas acabam ocupando uma área menor do que poderiam e ainda ficariam mais frágeis (RIDLEY, 1996). 
Luciano Zanetti Pessoa Candiotto; Fábio Alves de Vargas

A fragmentação florestal também ocasiona a diminuição de determinadas populações e de sua variabilidade genética. Em curto prazo, isso pode levar a uma deriva genética, de modo que genes ficariam afastados de sua população original. Em longo prazo, haveria uma endogamia decorrente da autofecundação e acasalamento entre indivíduos com grau de parentesco (KAGEYAMA; GANDARA; SOUZA, 1998).

Para Murcia (1995), os efeitos de borda se classificam em três tipos: (a) efeitos abióticos, que seriam as mudanças ambientais derivadas da aproximação com um habitat totalmente distinto; (b) efeitos biológicos diretos, que envolvem a variação na quantidade e distribuição das espécies, oriundas das condições físicas no entorno da borda; e (c) efeitos biológicos indiretos, que envolvem variações nas interações ecológicas, como por exemplo, predação, dispersão de sementes e competição.

\section{Efeitos da redução em APPs e RLs}

O desmatamento está diretamente ligado a processos erosivos e ao carreamento de sedimentos, nutrientes e poluentes aos corpos hídricos, sobretudo quando as florestas e outros tipos de vegetação nativa são substituídos por lavouras e pastagens. Há também problemas com o lançamento de efluentes industriais e domésticos sem o devido tratamento e, ainda, a ocupação das margens de cursos d'água para atividades humanas. Estas atividades causam aos corpos hídricos assoreamento do leito, aumento da temperatura, desequilíbrio químico e poluição da água (LIMA; ZAKIA, 2001).

A erosão na área rural geralmente ocasiona o empobrecimento do solo e a perda de seu potencial produtivo. Ademais, eleva as taxas de sólidos em suspensão na água que, de imediato aumentam a turbidez, implicando redução nas taxas de fotossíntese, bem como prejudicando a busca por alimentos para algumas espécies aquáticas, em decorrência de desequilíbrios na teia alimentar.

Os rios têm fluxo unidirecional e fluem sempre de cima para baixo. Assim, as perturbações podem ser transmitidas rio acima ou rio abaixo, através do movimento de materiais e organismos pela água. Dessa forma, a perda de conectividade ecológica e o isolamento das partes superiores da bacia hidrográfica podem ser prejudiciais à conservação (MOULTON; SOUZA, 2006). 
Luciano Zanetti Pessoa Candiotto; Fábio Alves de Vargas

O desmatamento ainda afeta o ciclo ecológico em uma escala regional, prejudicando a drenagem e o estoque de águas superficiais e subterrâneas, reduzindo a precipitação pela maior incidência de luz e também a ciclagem dos nutrientes (JACKSON et al., 2001).

Tundisi e Matsumura-Tundisi (2010) afirmam que o conjunto de processos ecológicos sustentado pela vegetação nativa tem componentes econômicos fundamentais na renovação da qualidade da água; no controle e recarga dos aquíferos e na água reposta por evapotranspiração; no controle de sedimentação dos ecossistemas aquáticos e, portanto, na preservação do volume de água; no suprimento de matéria orgânica para a fauna íctica e manutenção dos estoques e diversidade dessa fauna; e, na diversidade da fauna terrestre e refúgio para esta fauna, além de zona de reprodução. Qualquer deterioração da qualidade da água aumenta os custos com o tratamento para o abastecimento público, devido à necessidade de se aumentar o uso de floculantes, coagulantes e desinfetantes. Assim, ainda há perda nos serviços de recreação, turismo e pesca.

É importante ressaltar que a remoção de florestas ripárias tem um efeito negativo, pois influencia na degradação da qualidade das águas superficiais e subterrâneas, acelerando a sedimentação de lagoas, represas e rios, diminuindo assim o estoque de água nas nascentes e aquíferos. A preservação dessas áreas é primordial para regulação do ciclo hidrológico, bem como dos ciclos biogeoquímicos (TUNDISI; MATSUMURA-TUNDISI, 2010).

As florestas ripárias possuem funções importantes para a integridade de sistemas aquáticos e para os peixes. Essas funções se intensificam em rios menores e nascentes (BARRELA et al., 2001). Casatti (2010) lembra também que a maioria das espécies de peixes de água doce do país vive nos pequenos riachos, dependendo assim da presença de matas ripárias. A supressão da floresta leva ao aumento da temperatura das águas e da quantidade de algas, que por sua vez causam eutrofização nos rios e provocam a morte de peixes.

A quantidade e o tipo da luz que adentra ao corpo hídrico prejudicam a orientação visual dos peixes na busca de alimentos e no reconhecimento de parceiros. Os peixes também utilizam áreas mais escuras para escaparem de seus predadores. Com a diminuição das florestas ripárias ocorre a homogeneização da luz, prejudicando o desempenho dos peixes. A radiação Ultra Violeta também pode interferir, ocasionando até a morte das larvas de diversas espécies de peixes tropicais (PUSEY; ARTHINGTON, 2003; PUSEY et al., 2001).

No Brasil são encontradas 2.587 espécies de peixes de água doce (cerca de $37 \%$ das espécies de vertebrados conhecidos). Desse total, apenas 200 espécies estão mais diretamente ligadas a grandes rios (BUCKUP; MENEZES; GHAZZI, 2007; LEWINSOHN; PRADO, 2005; BUCKUP, 1999). Sendo assim, a maioria de espécies de peixes de água doce se 
Luciano Zanetti Pessoa Candiotto; Fábio Alves de Vargas

encontra em rios de pequeno porte, tendo uma alta relação com florestas ripárias. Estes regulam as populações de insetos aquáticos e algas, processam matéria orgânica e influenciam na cadeia alimentar e na alimentação humana (CASATTI, 2010).

Os peixes são ectotérmicos (não regulam sua temperatura). Assim, dependem da temperatura externa para ajustar a temperatura de seu corpo. Sem a floresta ou com sua diminuição o meio aquático, os peixes são expostos a temperaturas mais elevadas, afetando o controle metabólico desses organismos (PUSEY; ARTHINGTON, 2003).

O aumento da temperatura eleva a proporção de gases dissolvidos, diminuindo a tolerância dos peixes a substâncias tóxicas. Também afeta a reprodução dos peixes, pois a temperatura destes é regulada desde a maturação gonadal até o desenvolvimento das larvas (LLEWELLYN, 1973; LOWE-McCONNELL, 1999).

Esse aumento de temperatura afeta ainda diversas características dos ecossistemas, como por exemplo: a densidade da água, a taxa de sedimentação do fitoplâncton, a tensão superficial, as reações químicas e o metabolismo dos organismos aquáticos.

As florestas ripárias promovem abrigo para os peixes através de raízes, galhos e folhas, auxiliam como marcação na navegação e influenciam o perfil hidráulico do corpo hídrico (ANGERMEIER; KARR, 1984; CROOK; ROBERTSON, 1999).

Toledo et al. (2010) acrescentam que anfíbios se reproduzem na água, mas usam as matas ciliares para abrigo e alimentação. Dessa maneira, a diminuição da mata nativa promove a redução e fragmentação de habitats, com consequências como endogamia (cruzamento entre parentes), levando à perda de diversidade genética, além do aumento da radiação que promove a insolação direta sobre os ovos, larvas e girinos. Assim, as perturbações que impliquem redução de populações podem acarretar em desequilíbrios ecológicos.

Há um fluxo direto entre o sistema aquático e terrestre. Ao mesmo tempo em que o meio terrestre exporta elementos orgânicos, este recebe uma grande quantia de insetos e anfíbios que passam a fase juvenil apenas na água e, são responsáveis por processos no meio terrestre (MARCZAK; RICHARDSON, 2007).

Ademais, pesquisadores como Galetti et al. (2010), Develey e Pongiluppi (2010) e Freitas (2010), lembram que existe um grande número de espécies de mamíferos semiaquáticos, como ariranhas e lontras, que dependem destas matas ciliares, além de diversas espécies de aves e borboletas ameaçadas de extinção que vivem nessas áreas. Marques et al. (2010) discutiram os impactos das alterações para os répteis. 
Luciano Zanetti Pessoa Candiotto; Fábio Alves de Vargas

\section{CONSIDERAÇÕES FINAIS}

A priorização dos aspectos econômicos tem balizado a relação natureza-sociedade em detrimento dos aspectos sociais e ambientais, gerando uma contradição diante dos anseios e da busca por um desenvolvimento "sustentável".

Após a análise de algumas das principais alterações derivadas do Novo Código Florestal Brasileiro e de suas potenciais consequências, percebe-se que, ao invés de proporcionar segurança jurídica, a Lei $\mathrm{n}^{\circ} 12.651$ de 2012 fragilizou a proteção ambiental no Brasil, vez que abriu espaço para uma diminuição generalizada das florestas e outros habitats, o que pode ocasionar consequências desastrosas não apenas para a biota local, mas para o bem estar de toda a sociedade.

Por um lado, a nova Lei pode trazer avanços importantes, no sentido de permitir a implantação efetiva de formas de proteção e recuperação da vegetação nativa existente em propriedades rurais particulares no Brasil, como é o caso do Programa de Regularização Ambiental (caso seja devidamente implementado). Por outro, abriu espaço para retrocessos na proteção e recuperação da vegetação nativa e na manutenção de serviços ambientais.

A edição e a aprovação da nova lei não levou em consideração os diversos alertas da comunidade científica em relação aos danos ambientais potenciais ressaltados nesse artigo. Prevaleceram intencionalidades e privilégios de ruralistas, empresários e políticos.

Diversos estudos sugerem que muitas das alterações da Lei $\mathrm{n}^{\circ} 12.651$ de 2012 fragilizam a recuperação de processos ecológicos essenciais, comprometem a integridade dos atributos de Áreas de Preservação Permanentes e de Reservas Legais e relativizam o dever de reparar o dano ambiental. Essas situações ferem os preceitos do art. $3^{\circ}$ e 225 da Constituição Federal e deveriam ter sido consideradas.

Existe ainda uma carência de estudos de valoração de serviços ecossistêmicos prestados pela presença de vegetação nativa na propriedade rural, em particular para a agricultura em termos de polinização, controle de pragas, controle de erosão, proteção contra o vento e manutenção e proteção de recursos hídricos. Contudo, qualquer alteração em seu corpo legislativo que se traduza em diminuição de vegetação nativa atual, seja em Áreas de Preservação Permanentes, seja em Reservas Legais, necessitaria de um embasamento técnico e científico que contemplasse não só a conservação da natureza, mas também a economia, a saúde e o bem estar da população humana.

É importante ressaltar que, assim como a biodiversidade é patrimônio comum de todos os cidadãos, sua conservação é igualmente responsabilidade de todos. Assim, a 
Luciano Zanetti Pessoa Candiotto; Fábio Alves de Vargas

conservação não pode estar restrita às áreas de proteção sob a tutela do Estado, pois todo cidadão brasileiro deve contribuir para a efetiva conservação do meio ambiente.

Isso deve ser traduzido por uma ação proativa de todos em busca de uma cobrança efetiva, não só dos legisladores, mas também dos Poderes Executivo e Judiciário, para que toda a normatização ambiental atenda o dever de proteção ambiental previsto no artigo 225, caput, da Constituição da República, bem como de lhes exigir a reparação dos danos ambientais causados (art. 225, $\S 3^{\circ}$ ) e a restauração de processos ecológicos essenciais (art. $225, \S 1^{\circ}$, III). Exigências que encontram seus fundamentos na função social da propriedade rural, bem como no princípio da vedação de retrocesso em matéria socioambiental.

Contudo, conforme discutido nesse artigo, há uma tendência de intensificação de diversos impactos ambientais com as alterações do Código Florestal brasileiro. Isso indica que determinadas intencionalidades econômicas e políticas prevaleceram sobre os interesses coletivos de garantia de um meio ambiente equilibrado e fundamental para a qualidade de vida da população brasileira.

\section{Notas}

${ }^{1}$ Dispositivo questionado pela ADI 4903.

2VALERA, Carlos Alberto e ELLOVITCH, Mauro da Fonseca (Colaboradores). Manual Novo Código Florestal. In: MPMG Jurídico - Revista do Ministério Público do Estado de Minas Gerais, 2013, p.8.

${ }^{3}$ Dispositivo questionado pelas ADIs 4903 e 4937.

${ }^{4}$ Módulo fiscal é uma unidade de medida, em hectares, cujo valor é fixado pelo INCRA para cada município levando-se em conta: (a) o tipo de exploração predominante no município (hortifrutigranjeira, cultura permanente, cultura temporária, pecuária ou florestal); (b) a renda obtida no tipo de exploração predominante; (c) outras explorações existentes no município que, embora não predominantes, sejam expressivas em função da renda ou da área utilizada; (d) o conceito de "propriedade familiar" (LANDAU et al., 2012).

${ }^{5}$ VALERA e ELLOVITCH, op. cit., p. 9. Dispositivo questionado pelas ADIs 4902 e 4937

${ }^{6}$ Dispositivo questionado pela ADI 4901.

${ }^{7}$ Dispositivo questionado pela ADI 4902.

${ }^{8}$ VALERA e ELLOVITCH, op. cit., p. 10

${ }^{9}$ Dispositivo questionado pela ADI 4901.

10 SBPC e ABC - SOCIEDADE BRASILEIRA PARA O PROGRESSO DA CIÊNCIA E ACADEMIA BRASILEIRA DE CIÊNCIAS (Brasília) (Ed.). Propostas e considerações da Sociedade Brasileira para o Progresso da Ciência (SBPC) e Academia Brasileira de Ciências (ABC) acerca da reforma do Código Florestal (PLC 30/2011). São P: SBPC, 2011. 28 p.

${ }^{11}$ SBPC e ABC, op. cit., p. 5. 
Luciano Zanetti Pessoa Candiotto; Fábio Alves de Vargas

\section{Referências}

AB'SÁBER, A. N. A organização natural das paisagens inter e subtropicais brasileiras. Geomorfologia, São Paulo, n. 41, p. 1-39, 1973.

Do Código Florestal para o Código da Biodiversidade. In: Biota Neotropica, São Paulo, 2010. Disponível em:<http://www.biotaneotropica.org.br/v10n4/pt/fullpaper?bn01210042010+pt>. Acesso em: 20 abr. 2017.

ANGERMEIER, P.L.; KARR, J.R. Fish communities along environmental gradients in a system of tropical streams. In: Evolutionary ecology of neotropical freshwater fishes (T.M. Zaret, ed.). The Hague, Netherlands, p. 39-57, 1984.

BARRELA, W. et al. As relações entre as matas ciliares, os rios e os peixes. In: Matas ciliares: conservação e recuperação (R.R. Rodrigues \& H.F. Leitão Filho, ed.). EDUSP, FAPESP, São Paulo, p.187-207, 2001.

BRASIL. Constituição da República Federativa do Brasil: promulgada em 5 de outubro de 1988. $29^{a}$ ed. Atual. Ampl. São Paulo: Saraiva, 2002.

Lei Federal $\mathbf{n}^{\circ}$ 6.938, de 31 de agosto de 1981. Institui a Política Nacional do Meio Ambiente. Diário Oficial da República Federativa do Brasil. Brasília, 1981.

Lei $\mathbf{n}^{\mathbf{0}}$ 12.651, de 25 de maio de 2012. Dispõe sobre a proteção da vegetação nativa; altera as Leis nos 6.938, de 31 de agosto de 1981, 9.393, de 19 de dezembro de 1996, e 11.428, de 22 de dezembro de 2006; revoga as Leis nos 4.771, de 15 de setembro de 1965, e 7.754, de 14 de abril de 1989, e a Medida Provisória no 2.166-67, de 24 de agosto de 2001; e dá outras providências. Presidência da República, Casa Civil.

Decreto $\mathbf{n}^{\mathbf{0}}$ 7.830, de 17 de outubro de 2012. Dispõe sobre o Sistema de Cadastro Ambiental Rural, o Cadastro Ambiental Rural, estabelece normas de caráter geral aos Programas de Regularização Ambiental, de que trata a Lei n. ${ }^{\circ}$ 12.651, de 25 de maio de 2012, e dá outras providências. Presidência da República, Casa Civil.

Decreto $\mathrm{n}^{\mathbf{0}}$ 8.235, de 05 de maio de 2014. Estabelece normas gerais complementares aos Programas de Regularização Ambiental dos Estados e do Distrito Federal, de que trata o Decreto n. ${ }^{\circ}$ 7.830, de 17 de outubro de 2012, institui o Programa Mais Ambiente Brasil, e dá outras providências. Presidência da República, Casa Civil.

Decreto $\mathrm{n}^{\circ}$ 9.257, de 29 de dezembro de 2017. Prorroga o prazo de inscrição ao Cadastro Ambiental Rural - CAR. Presidência da República, Casa Civil.

BUCKUP, P.A. Sistemática e biogeografia de peixes de riachos. In: Ecologia de peixes de riachos(E.P. Caramaschi, R. Mazzoni e P.R. Peres-Neto, ed.). Série Ecologia Brasiliensis, PPGEUFRJ, Rio de Janeiro, v.6, p. 91-138, 1999.

BUCKUP, P.A.; MENEZES, N.A.; GHAZZI, M.S. Catálogo das espécies de peixes de água doce do Brasil. Museu Nacional, Rio de Janeiro, 2007.

CASATTI, L.; FERREIRA, C.P.; CARVALHO, F.R. Grass-dominated stream sites exhibit low fish species diversity and dominance by guppies: an assessment of two tropical pasture river basins.Hydrobiologia, n. 632, p. 273-283, 2009. 
Luciano Zanetti Pessoa Candiotto; Fábio Alves de Vargas

CASATTI, L. Alterações no Código Florestal Brasileiro: Impactos potenciais sobre a ictiofauna. In: Biota Neotropica, São Paulo, 2010. Disponível em: <http://www.biotaneotropica.org.br/v10n4/pt/fullpaper?bn00310042010+pt $>$. Acesso em: 20 abr. 2017.

DEVELEY, P. F.; PONGILUPPI, T. Impactos potenciais na avifauna decorrentes das alterações propostas para o Código Florestal Brasileiro. In: Biota Neotropica, São Paulo, 2010. Disponível em: <http://www.biotaneotropica.org.br/v10n4/pt/abstract?article+bn00610042010> Acesso em: 16 ago.2017.

FREITAS, A. V. L. Impactos potenciais das mudanças propostas no Código Florestal Brasileiro sobre as borboletas. In: Biota Neotropica, São Paulo, 2010. Disponível em: <http://www.biotaneotropica.org.br/v10n4/pt/abstract?article+bn00810042010> Acesso em: 16 ago.2017.

GALETTI, M. et al. Mudanças no Código Florestal e seu impacto na ecologia e diversidade dos mamíferos no Brasil. In: Biota Neotropica, São Paulo, 2010. Disponível em: <http://www.biotaneotropica.org.br/v10n4/pt/fullpaper?bn00710042010+pt $\geq$. Acesso em: 20 abr. 2017.

JACKSON, R. B. et al. Water in a changing world. Ecological applications II, v. 4, p. 1027-1045, 2001.

KAGEYAMA, P. Y; GANDARA, F. B.; SOUZA, L. M. I. Consequências Genéticas da Fragmentação sobre Populações de Espécies Arbóreas. Série técnica IPEF, Piracicaba, v. 12, p. 65-70, 1998.

LANDAU, E. C. et al. Variação Geográfica do Tamanho dos Módulos Fiscais no Brasil. Sete Lagoas - Mg: Embrapa, 2012. 200 p. Disponível em: <https://www.infoteca.cnptia.embrapa.br/bitstream/doc/949260/1/doc146.pdf>. Acesso em: 20 jan. 2018.

LEHFELD, L. de S.; CARVALHO, N. C. B.; BALBIM, Leonardo Isper Nassif. Código Florestal comentado e anotado (artigo por artigo). 2. ed. São Paulo: Método, 2013.

LEUZINGER, M.D.; CUREAU, S. Direito ambiental. Rio de Janeiro: Elsevier, 2008.

LEWINSOHN, T.M.; PRADO, P.I. Quantas espécies há no Brasil? Megadiversidade, v. 1, p. 36-42, 2005.

LEWINSOHN, T. M. et al. Impactos potenciais das alterações propostas para o Código Florestal Brasileiro na biodiversidade e nos serviços ecossistêmicos. Disponível em: <http://www2.unesp.br/revista/wp-content/uploads/2010/10/Biota-Fapesp-ABECO-Sitese-CFB-ebiodiversidade.pdf>. Acesso em: 16 ago. 2017.

LIMA, W. P.; ZAKIA, M. J. Hidrologia de matas ciliares. Instituto de Pesquisas e Estudos florestais, Piracicaba, São Paulo. 2001.

LOWE-McCONNELL, R.H. Estudos ecológicos de comunidades de comunidades de peixes tropicais. EDUSP, São Paulo, 1999.

MACHADO, P. A. L. Direito Ambiental Brasileiro. 4. Ed. São Paulo: Malheiros Editores, 1992.

MARCZAK, L.B.; RICHARDSON, J.S. Spiders and subsidies: results from the riparian zone of a coastal temperate rainforest. J. An. Ecol, v. 76, p. 687-694, 2007. 
Luciano Zanetti Pessoa Candiotto; Fábio Alves de Vargas

MARQUES, Otavio Augusto Vuolo et al. Impactos potenciais das mudanças propostas no Código Florestal Brasileiro sobre os répteis brasileiros. In: Biota Neotropica, São Paulo, 2010. Disponível em:<http://www.biotaneotropica.org.br/v10n4/pt/fullpaper?bn00510042010+pt >. Acesso em: 20 abr. 2017.

METZGER, J. P. O Código Florestal tem base científica? Natureza \& Conservação, São Paulo, v. 1, n. $8, \quad$ p.1-8, jun. 2010. Disponível em: <http://www.lerf.esalq.usp.br/divulgacao/recomendados/artigos/metzger2010.pdf>. Acesso em: 13 set. 2017.

MURCIA, C. Edge effects in fragmented forests: implications for conservation. Trends in Ecology and Evolution, v. 10, p. 58-62, 1995.

NAIMAN, R. J. et al. Fundamental elements of ecologically healthy watersheds in the Pacific Northwest coastal region. In: NAIMAN, R. J., ed. Watershed management: balancing sustainability and evironmental change. New York: Springer-Verlag, 1992. p. 127-174.

NOBRE, P. et al. Amazon Deforestation and Climate Change in a Coupled Model Simulation. Journal of Climate, v. 22, p. 5686-5697, 2009.

PUSEY, B.J.; ARTHINGTON, A.H. Importance of the riparian zone to the conservation and management of freshwater fish: a review. Mar. Fresh. v. 54, p. 1-16, 2003.

PUSEY, B.J.; ARTHINGTON, A.H.; CLOSE, P.G.; BIRD, J. Larval fishes in rainforest streams: patterns of abundance and microhabitat use. J. Roy. Soc. Queensland, v. 110, p. 27-96, 2001.

RIBEIRO, K. T.; FREITAS, L. Impactos potenciais das alterações no Código Florestal sobre a vegetação de campos rupestres e campos de altitude. In: Biota Neotropica, São Paulo, 2010. Disponível em:<http://www.biotaneotropica.org.br/v10n4/pt/fullpaper?bn04310042010+pt $\geq$. Acesso em: 20 abr. 2017.

RIDLEY, M. Evolution. Malden: Blackwell Science, 1996.

SAUNDERS, D. A.; HOBBS, R. J.; MARGULES, C. R. Biological consequences of ecosystem fragmentation: a review. Conservation Biology v. 5, p. 18-32, 1991.

SILVA, J. A. A. et al.. O Código Florestal e a Ciência: contribuições para o diálogo. ISBN 978-8586957-16-1, São Paulo: Sociedade Brasileira para o Progresso da Ciência, SBPC; Academia Brasileira de Ciências, ABC. 2011. 124 p.

TABARELLI, M.; LOPES, A. V. F.; PERES, C. Edge-effects drive tropical forest fragments towards an early-successional system. Biotropica, Lawrence, v. 40, p. 657-661, 2008.

TOLEDO, L. F. et al. A revisão do Código Florestal Brasileiro: impactos negativos para a conservação dos anfíbios. In: Biota Neotropica, São Paulo, 2010. Disponível em: <http://www.biotaneotropica.org.br/v10n4/pt/fullpaper?bn00410042010+pt $>$. Acesso em: 20 abr. 2017.

TUNDISI, J.G.; TUNDISI, T.M. Limnologia. Oficina de Textos, São Paulo, 2008.

TUNDISI, J. G.; TUNDISI, T. M. Impactos potenciais das alterações do Código Florestal nos recursos hídricos. In: Biota Neotropica, São Paulo, 2010. Disponível em:〈http://www.biotaneotropica.org.br/v10n4/pt/fullpaper?bn01110042010+pt $>$. Acesso em:20 abr.2017. 
Luciano Zanetti Pessoa Candiotto; Fábio Alves de Vargas

VALERA, C. A.; EllovitCH, M. da F. (Colaboradores). Manual Novo Código Florestal. In: MPMG Jurídico - Revista do Ministério Público do Estado de Minas Gerais, 2013.

VIANA, V. M.; TABANEZ, A. A. J.; MARTINS, J. L. A. Restauração e manejo de fragmentos florestais. Anais do Congresso nacional sobre essências nativas. São Paulo: Instituto Florestal de São Paulo, p. 400-407, 1992. 